\title{
Serum Dickkopf-1 as a potential prognostic marker in patients with rheumatoid arthritis
}

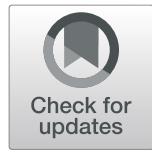

\author{
Dina A. Ali ${ }^{1}$, Doaa Mohamed Esmail ${ }^{2}$, Haidy Ali Mohammed ${ }^{3 *}$, Reham Lotfy Yonis ${ }^{4}$ and \\ Radwa Mahmoud El-Sharaby ${ }^{5}$
}

\begin{abstract}
Background: Rheumatoid arthritis (RA) is a disease of an autoimmune nature that involves all types of joints structures and manifested by chronic joints inflammations and thus their erosions and damage. Dickkopf-1 (DKK-1) is a molecule that has an inhibitory regulation of wingless/integrated genes (Wnt) pathway and has a major role in models of animals with arthritis or joint destruction. Increased DKK-1 levels are implicated in higher resorption of the bone in cases of rheumatoid arthritis and thus with higher probability for joint deformities, while low levels associated with formation of new bone by osteoblasts, we aimed to study the prognostic role of circulating Dickkopf-1 in rheumatoid arthritis.

Results: The present study revealed that the DKK-1 levels were significantly increased in RA patients in relation to the control group $(P=0.001)$. We found a significant positive correlation between DKK-1 level and ESR $(P=0.001)$, Disease Activity Score (DAS 28) $(P=0.001)$, the disease duration $(P=0.001)$, and the presence of bone erosions in plain $X$-ray of hands $(P=0.001)$. Moreover, we revealed that, at cutoff value 2150 , the DKK-1 in RA has $90 \%$ sensitivity and $85 \%$ specificity.

Conclusions: DKK-I serum level can be used as a potential prognostic biomarker for monitoring of joint erosions and destruction in RA patients. Furthermore, it could be a possible target molecule in the future therapy to control the process of joint destruction.
\end{abstract}

Keywords: Rheumatoid arthritis, Dickkopf-1, Bone erosions

\section{Background}

RA is chronic disease of an autoimmune nature that causes inflammation in the synovial membrane, resulting in invasion of the near cartilaginous matrix by synovial tissue, that leads to the cartilage and bone degradation inside the joints. These bone erosions are often seen in imaging as marginal erosions of the joint, and it is a predictive of a worse prognosis for the disease $[1,2]$.

Bony erosions which develop within the first few years after onset of the disease can cause not only pain, but also lead to gradual progressive disability that leads to heavy socio-economic burden in RA patients [3].

\footnotetext{
* Correspondence: haidyali26@yahoo.com

${ }^{3}$ Department of Internal Medicine and Rheumatology, Faculty of Medicine,

Tanta University, Tanta, Egypt

Full list of author information is available at the end of the article
}

Therefore, identification of the key molecule responsible for bony erosion at various RA stages may be beneficial to better understand pathogenesis of the disease and improve prognosis [4].

The bone matrix destruction in RA patients is mainly caused by increase of osteoclastic activity at the junction between cartilage and inflammatory pannus $[5,6]$. There is evidence that proteins which are synthesized by wingless/integrated gene cluster (Wnt) are essential mediators for genesis of osteoblasts. This Wnt signaling pathway is regulated by many groups of negative regulators, and one of these regulators is Dickkopf-1 (DKK-1) $[7,8]$.

Dickkopf (DKK) is a group of proteins rich in cysteine and consists of four subtypes (DKK-1, DKK-2, DKK-3, and DKK-4) or more $[9,10]$.

\section{Springer Open}

(อ) The Author(s). 2021 Open Access This article is licensed under a Creative Commons Attribution 4.0 International License, which permits use, sharing, adaptation, distribution and reproduction in any medium or format, as long as you give appropriate credit to the original author(s) and the source, provide a link to the Creative Commons licence, and indicate if changes were made. The images or other third party material in this article are included in the article's Creative Commons licence, unless indicated otherwise in a credit line to the material. If material is not included in the article's Creative Commons licence and your intended use is not permitted by statutory regulation or exceeds the permitted use, you will need to obtain permission directly from the copyright holder. To view a copy of this licence, visit http://creativecommons.org/licenses/by/4.0/. 
Table 1 Comparison between control and patient groups as regards age, sex, ESR 1h., DKK-1, RF, CRP, and anti-CCP

\begin{tabular}{|c|c|c|c|c|c|}
\hline & & Control & Cases & Test & $P$ value \\
\hline \multirow[t]{2}{*}{ Age (years) } & Range & $27-60$ & $25-58$ & T: 0.967 & 0.336 \\
\hline & Mean \pm SD & $45.50 \pm 9.42$ & $42.83 \pm 11.42$ & & \\
\hline \multirow[t]{2}{*}{ Sex } & Male (\%) & $9(45 \%)$ & $20(25 \%)$ & $X^{2}: 3.108$ & 0.078 \\
\hline & Female (\%) & $11(55 \%)$ & $60(75 \%)$ & & \\
\hline \multirow[t]{2}{*}{ ESR 1h. (mm.) } & Range & $4-11$ & $5-85$ & T: 7.556 & $0.001^{*}$ \\
\hline & Mean \pm SD & $8.30 \pm 2.00$ & $44.80 \pm 21.50$ & & \\
\hline \multirow{2}{*}{$\begin{array}{l}\text { DKK-1 } \\
\text { (pg/mL) }\end{array}$} & Range & $421.5-2657$ & $1650.8-10857.5$ & T: 6.982 & $0.001^{*}$ \\
\hline & Mean \pm SD & $1102.42 \pm 758.29$ & $5383.80 \pm 2973.45$ & & \\
\hline \multirow[t]{2}{*}{ RF (IU/ml) } & Positive (\%) & $0(0 \%)$ & $64(80 \%)$ & $X^{2}: 44.444$ & $0.001^{*}$ \\
\hline & Negative (\%) & $20(100 \%)$ & $16(20 \%)$ & & \\
\hline \multirow[t]{2}{*}{ CRP (mg/L) } & Positive (> 6) (\%) & $0(0 \%)$ & 67 (83.3\%) & $X^{2}: 50.758$ & $0.001^{*}$ \\
\hline & Negative $(<6)(\%)$ & $20(100 \%)$ & 13 (16.3\%) & & \\
\hline \multirow[t]{2}{*}{ Anti-CCP (u/ml) } & Range & $4-20$ & 35-195 & T: 9.632 & $0.001^{*}$ \\
\hline & Mean \pm SD & $12.67 \pm 3.24$ & $114.78 \pm 47.18$ & & \\
\hline
\end{tabular}

ESR 1 h erythrocyte sedimentation rate (first hour), $D K K-1$ Dickkopf-1, $R F$ rheumatoid factor, $C R P$ C-reactive protein, anti-CCP anti-cyclic citrullinated peptide antibody, $t$. test independent samples $t$ test, ${ }^{*} P \leq 0.05$ indicates significant difference

It was thought that DKK-1 has a major role in bone erosions in inflammatory articular diseases via Wnt and $\beta$-catenin pathway Wnt binds the Frizzled receptor and induces low-density lipoprotein receptor-related protein $5 / 6$ (LRP-5/6) phosphorylation, then activates glycogen synthase kinase. This cascade releases axin from its complex with $\beta$-catenin and allows $\beta$-catenin to translocate to the nucleus. The consequence is the increased expression of many target genes encoding proteins that control osteoblastic differentiation, apoptosis inhibition, and other proteins involved in Wnt signaling. Extracellular proteins inhibiting this pathway include sclerostin (SOST) and Dickkopf-related protein 1 (DKK-1) [11]. In the present study, we aimed to study the prognostic role of circulating Dickkopf-1 in rheumatoid arthritis.

\section{Methods}

\section{Study design and participants}

This cross-sectional study was conducted on 80 RA patients and 20 healthy controls matched in age and sex.
RA patients were chosen from the inpatient unit and outpatient clinic in the Rheumatology and Rehabilitation Department at our University Hospital from June 2020 to January 2021

\section{Inclusion criteria}

All RA patients were diagnosed according to the American College of Rheumatology (ACR)/European League against Rheumatism (EULAR) 2010 criteria for the diagnosis of RA [12].

\section{Exclusion criteria}

We excluded RA patients who had any other diseases that may cause inflammatory arthritis, patients with impaired liver and kidney functions, those complaining of other autoimmune disorders, and RA patients who were in ICU.

Written informed consent was obtained from the patients and controls at the beginning of the study, and our study was approved by the ethics committee at our

Table 2 Correlation between RF and DKK-1, ESR 1h., and DAS28

\begin{tabular}{|c|c|c|c|c|c|c|c|c|c|}
\hline $\mathrm{RF}(\mathrm{IU} / \mathrm{ml})$ & & Range & & & Mean & \pm & SD & $t$. test & $P$ value \\
\hline \multirow[t]{2}{*}{ DKK-1 (pg/mL) } & +ve & 1650.8 & - & 10857.5 & 5116.35 & \pm & 2996.61 & 2.643 & 0.108 \\
\hline & -ve & 1684.9 & - & 8957.2 & 6453.63 & \pm & 2706.29 & & \\
\hline \multirow[t]{2}{*}{ ESR 1h. (mm) } & +ve & 5 & - & 85 & 43.80 & \pm & 22.14 & 0.694 & 0.407 \\
\hline & -ve & 14 & - & 67 & 48.81 & \pm & 18.79 & & \\
\hline \multirow[t]{2}{*}{ DAS28 } & +ve & 3.5 & - & 7.5 & 5.45 & \pm & 1.20 & 0.112 & 0.738 \\
\hline & -ve & 3.5 & - & 7.4 & 5.56 & \pm & 1.37 & & \\
\hline
\end{tabular}

RF rheumatoid factor, DKK-1 Dickkopf-1, ESR 1h. erythrocyte sedimentation rate (first hour), DAS28 Disease Activity Score using 28 joints count, $t$. test independent samples $t$ test, ${ }^{*} P \leq 0.05$ indicates significant difference 
Table 3 Correlation between CRP and DKK-1, ESR 1h., and DAS28

\begin{tabular}{|c|c|c|c|c|c|c|c|c|c|}
\hline CRP (mg/L) & & Range & & & Mean & \pm & SD & $t$. test & $P$ value \\
\hline \multirow[t]{2}{*}{ DKK-1 (pg/mL) } & $+v e$ & 1650.8 & - & 10857.5 & 5127.03 & \pm & 2931.78 & 3.159 & 0.079 \\
\hline & $-v e$ & 1748.9 & - & 8957.2 & 6707.18 & \pm & 2943.83 & & \\
\hline \multirow[t]{2}{*}{ ESR 1h. (mm) } & +ve & 5 & - & 85 & 43.94 & \pm & 21.92 & 0.657 & 0.420 \\
\hline & -ve & 18 & - & 67 & 49.23 & \pm & 19.34 & & \\
\hline \multirow[t]{2}{*}{ DAS28 } & +ve & 3.5 & - & 7.5 & 5.44 & \pm & 1.19 & 0.239 & 0.626 \\
\hline & $-v e$ & 3.5 & - & 7.4 & 5.62 & \pm & 1.44 & & \\
\hline
\end{tabular}

CRP C-reactive protein, DKK-1 Dickkopf-1, ESR 1 h., erythrocyte sedimentation rate (first hour), DAS28 Disease Activity Score using 28 joints count, $t$. test independent samples $t$ test, ${ }^{*} P \leq 0.05$ indicates significant difference

university, approval number $33451 / 5 / 20$ and it was conducted in accordance with the Declaration of Helsinki.

All groups will be subjected to detailed medical history, with complete clinical examination with assessment of disease activity using Disease Activity Score using 28 joints count (DAS28) [13], and plain X-ray on the hands for assessment of radiographic damage.

\section{Laboratory investigations Blood sampling}

Ten milligrams of venous blood samples were collected from all participants after $12 \mathrm{~h}$ of overnight fasting, blood samples subdivided into $3 \mathrm{ml}$ on EDTA containing tubes for complete blood picture (CBC), $1.6 \mathrm{ml}$ blood on $0.4 \mathrm{ml}$ tri sodium citrate tube for erythrocyte sedimentation rate (ESR), and the rest of blood on plain tube which centrifugated on $3000 \mathrm{rpm} 15 \mathrm{~min}$ for serum separation for measuring CRP and RF; serum was stored at $-80^{\circ} \mathrm{C}$ until analysis.

\section{Laboratory tests}

1. Complete blood picture (CBC): $\mathrm{RBC}$ count, hemoglobin concentration, total and differential leucocytic count, and platelet count on ERMA PCE-210N cell counter.

2. Erythrocyte sedimentation rate (ESR in $\mathrm{mm} / \mathrm{h}$ ) was measured by using the Westergren method [14].

3. C-reactive protein (CRP in $\mathrm{mg} / \mathrm{L}$ ) using turbidmetric method on Beckman Coulter AU 480 Analyzers (lot number 2550).

4. Rheumatoid factor (RF) using nephlometric technique on Konelab 60 i Thermo Scientific (Thermo Scientific - Finland) autoanalyzer. (Catalogue Number: 981920 lot number P132).

5. The anti-CCP IgG (anti-CCP in U/ml) level was measured using electro-chemiluminescence immunoassay on automated immunoassay analyzer, Cobas e411, Roche Diagnostics GmbH, Germany, using kit Catalog no: 05031656.

6. Measurement of serum level of DKK-1 using Quantikine Human DKK-1 immunoassay manufactured and distributed by R\&D kit (catalog number DKK100B) USA (Quantikine 2011) and read on the microplate reader (Stat $\mathrm{Fax}^{\oplus} 2100$, Fisher Bioblock Scientific, France).

\section{Statistical analysis}

Statistics were performed using SPSS program, version 17 (SPSS Inc., Chicago, IL, USA) and the Graph-Pad Prism software (GraphPad Prism Software Inc., San Diego, California, USA).

Statistical presentation and analysis of the present study was conducted as continuous data and was expressed as mean \pm standard deviation or median. Comparison of continuous data between two groups was made by using Student's $t$ test and Mann-Whitney tests, and for categorical variables, chi-square test was used. Spearman correlation between different parameters was used. Statistical significance was defined as a $P$ value of $\leq 0.05$. The sensitivity, specificity, and accuracy were calculated by using receiver-operating characteristic analysis (ROC curve).

\section{Results}

This study included 80 patients with RA and 20 controls. There was no significant difference between studied groups as regards age or sex $(P=0.336,0.078)$, respectively. But there was a significant increase in serum ESR, DKK-1, RF, CRP, and also anti-CCP levels in patients in comparison with controls $(P=0.001)$ (Table 1$)$.

The RF was negative in all controls (100\%). In RA patients, RF was positive in 64 out of 80 patients $(80 \%)(P=$ 0.001).

Table 4 Correlation between serum ESR, DAS28, and DKK-1

\begin{tabular}{llll}
\hline & & DKK-1 $(\mathbf{p g} / \mathrm{mL})$ & ESR 1st $\mathbf{h}$. \\
\hline ESR 1 h. (mm.) & $r$ & 0.845 & \\
& $P$ value & $0.001^{*}$ & \\
DAS 28 & $r$ & 0.818 & 0.736 \\
& $P$ value & $0.001^{*}$ & $0.001^{*}$ \\
\hline
\end{tabular}

DKK-1 Dickkopf-1, ESR 1h. erythrocyte sedimentation rate (first hour), DAS28 Disease Activity Score using 28 joints count, Pearson's correlation coefficient, ${ }^{*} P \leq 0.05$ indicates significant difference 


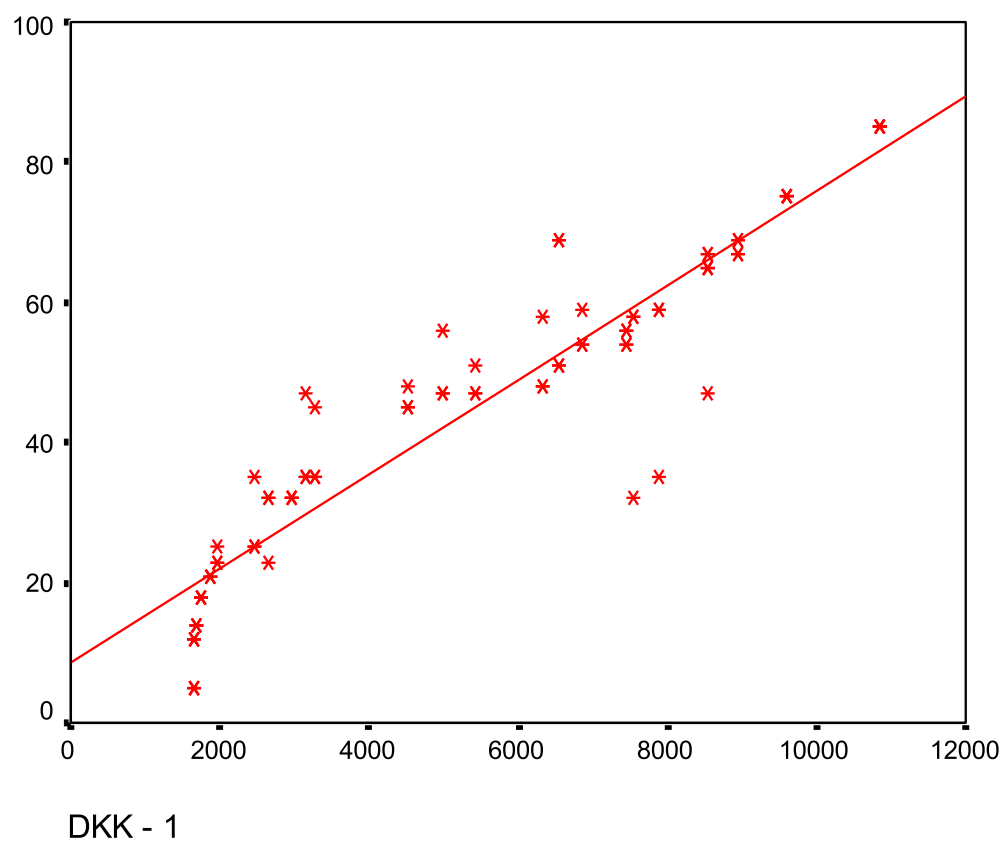

Fig. 1 A positive significant correlation between DKK-1 serum level and ESR $(r=0.845)$ and $(P=0.001)$

The CRP level in the control group was negative in all controls (100\%). In RA patients, CRP was positive in 67 patients $(83.3 \%)$ and negative in 13 patients $(16.3 \%)(P=$ 0.001) (Table 1).

The disease duration in the patients' group ranged from 2 to 12 years with mean \pm SD, $6.9937 \pm 2.78633$.
In this study, we did not find significant correlation between both RF and CRP and other markers DDK-1, ESR, and DAS28 $(P=0.108,0.407,0.738)(P=0.079$, $0.420,0.626$ ) (Tables 2 and 3 , respectively).

A positive significant correlation was found between DKK-1 levels and ESR $(P=0.001)$, DKK-1, and DAS28

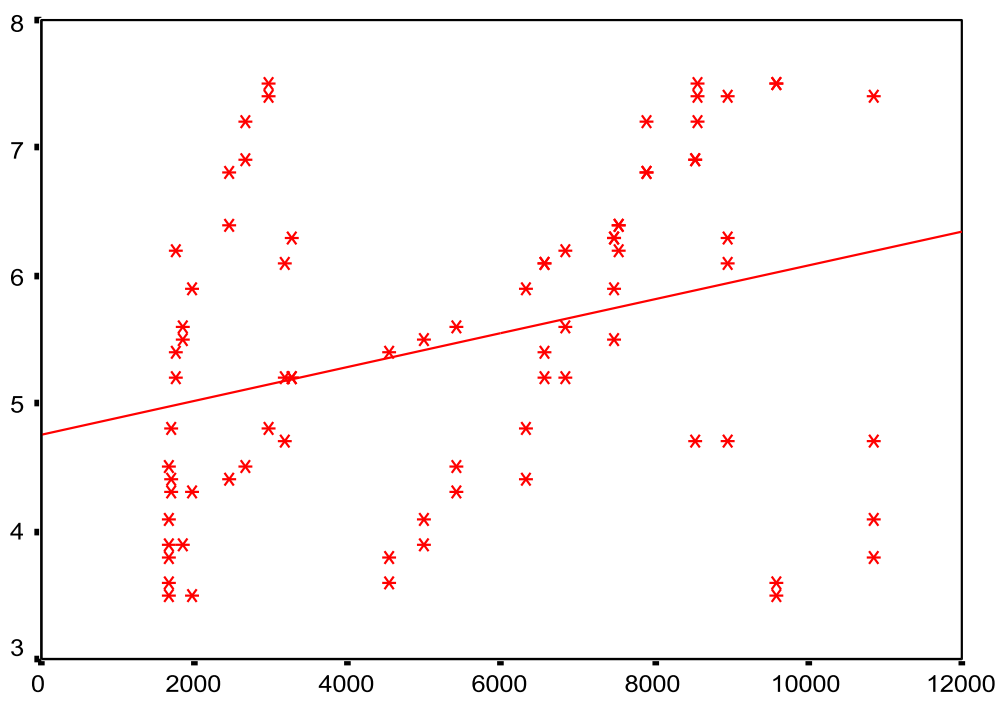

DKK - 1

Fig. 2 A positive significant correlation between serum DDK-1 level and DAS28 $(r=0.818)$ and $(P=0.001)$ 


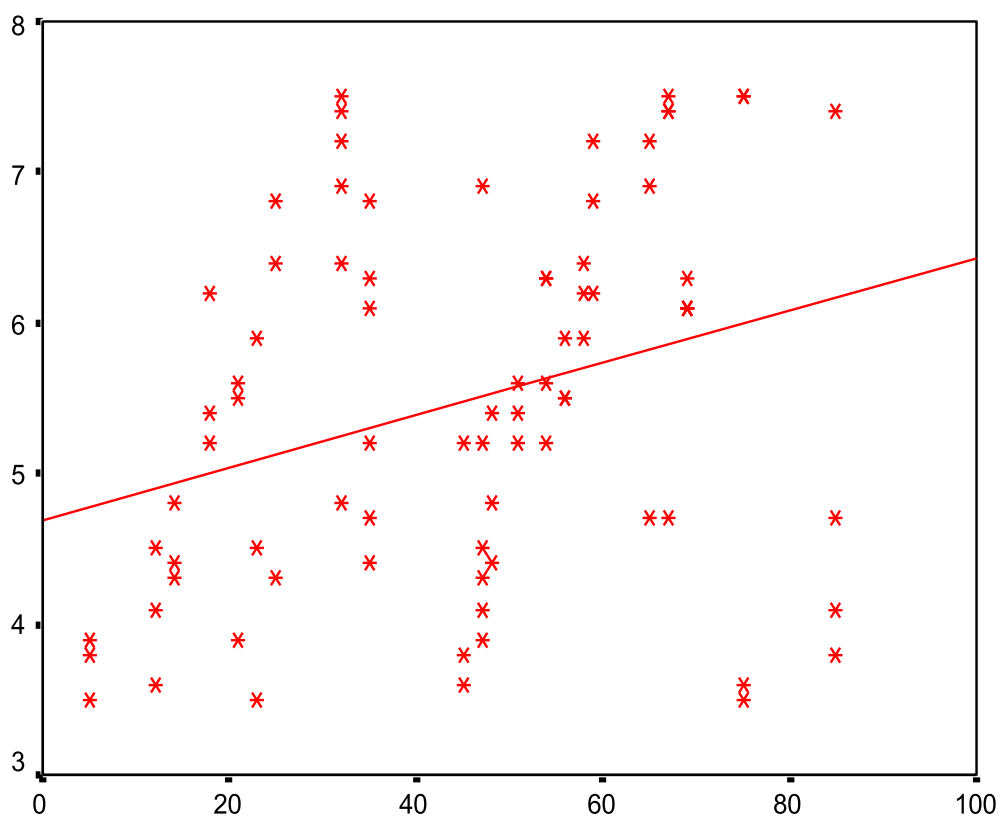

ESR 1h.

Fig. 3 A positive significant correlation between ESR and DAS $28(r=0.736)$ and $(P=0.001)$

$(P=0.001)$ and between ESR and DAS28 $(P=0.001)$

(Table 4, Figs. 1, 2, and 3, respectively).

Our results found a significant positive correlation between duration of the disease and serum levels of DKK$1(P=0.001)$. The duration of disease in RA patients ranged from 2.00 to 12.00 years with mean + SD (6.9937 \pm 2.78633 ) (Table 5, Fig. 4). We recorded a significant positive correlation between serum DKK-1 and antiCCP levels $(P=0.001)$ (Table 6, Fig. 5).

We found that 30 out of 80 patients (37.5\%) which had bony erosions in plain X-ray of the hands, and they had significant higher levels of serum DKK-1 than the other 50 patients $(62.5 \%)$ who had no erosions detected in their X-rays $(P=0.001)$ (Table 7$)$.

At cutoff value 2150 , the DKK-1 in RA has $82 \%$ accuracy, $75 \%$ negative predictive value, $95 \%$ positive predictive values, $90 \%$ sensitivity, and $85 \%$ specificity (Table 8 ).

Table 5 Correlation between serum DKK-1 levels and duration of the disease

\begin{tabular}{lll}
\hline & & DKK-1 \\
\hline Duration of the disease & $r$ & 0.824 \\
& $P$ value & $0.001^{*}$
\end{tabular}

DKK-1 Dickkopf-1, Pearson's correlation coefficient, ${ }^{*} P \leq 0.05$ indicates significant difference

\section{Discussion}

RA is a disease of autoimmune nature that affects mostly the articular structures and synovial membranes causing chronic inflammation involving multiple joints and body systems. The small joints of the hands and feet are often firstly affected, followed by larger joints. RA patients have periodic flare-up that can lead to irreversible joint damage, systemic affection, and organ damage as the heart and lungs [15].

Until now, although new modalities of treatment, severe joint damage and disability are common. Thus, early and effective treatment can change the prognosis of the disease, decrease mortality, and improve joint functions [16]. To meet the needs to improve the diagnostic and prognostic tests, multiple serum biomarkers are studied in RA, including many autoantibodies [17]. Wnt proteins are among these important biomarkers that related to disease prognosis.

The Wnt proteins were recognized as essential elements in normal homeostasis of the bone, specially formation of the new bone by osteoblasts [18] and also responsible for many cellular processes as maturation, differentiation, and programmed death.

These functions occur via attachment of Wnt proteins to a co-receptor complex that consists of low-density lipoproteins that called (receptor related proteins LRP5 or LRP6). Multiple pathways were found, but the Wnt bCatenin pathway is the major one involving bone stasis. 


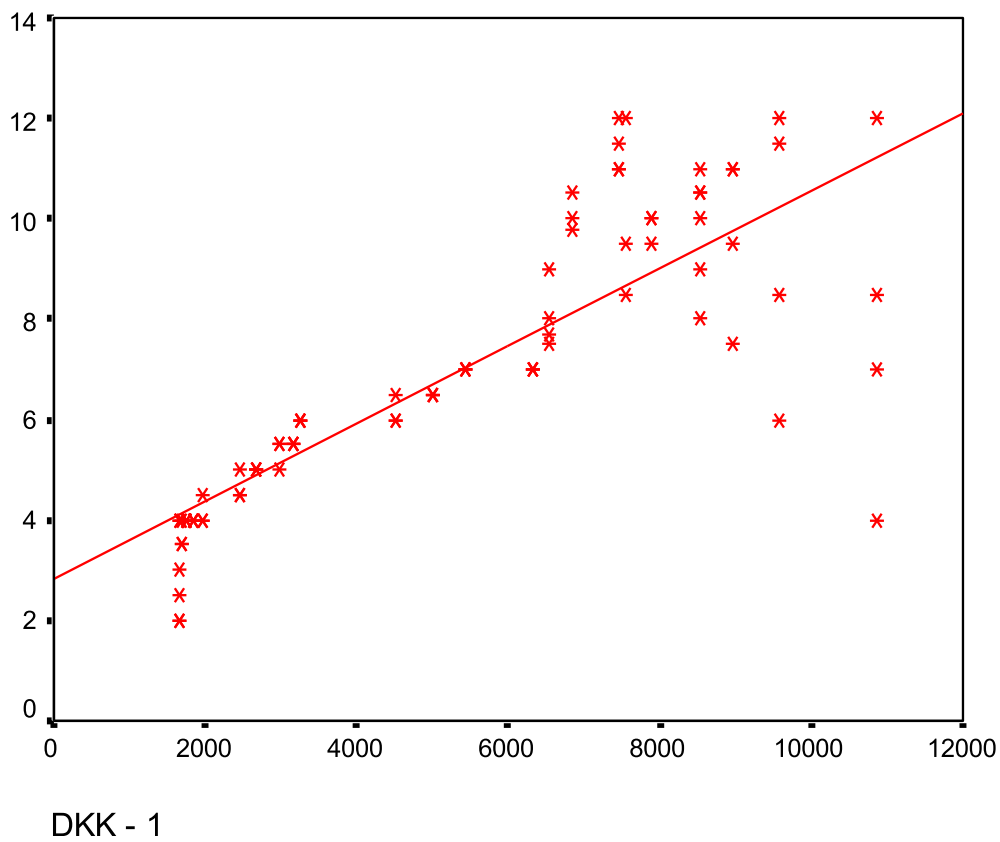

Fig. 4 Correlation between serum DKK-1 levels and duration of the disease $(r=0.824)$ and $(P=0.001)$

In this pathway, the attachment of Wnt proteins with the previously mentioned receptors results in inhibition of b-catenin degradation and so, an increase in intracellular b-catenin [19].

DKK-1 was proved to inhibit regulation of the Wnt pathway. In experimental trials on animals that had arthritis, it was found to have a role as a marker for joint destruction. Elevated DKK-1 levels were positively correlated to bone resorption, whereas its low levels were related to new bone formation. Moreover, Diarra et al. showed a negative regulation between DKK-1 and OPG. So that, DKK-1 was proven to have an indirect effect on genesis of osteoclasts and subsequent bony resorption and erosions. So, this dual action demonstrated that DKK-1 is a key regulator of pathogenic remodeling of joint, and this remodeling is based on the interplay of anabolic with catabolic pathways [18]. In other studies, DKK-1 blockage was found to make fusion of the sacroiliac joints in animals that had arthritis [20].

Table 6 Correlation between serum DKK-1 levels and anti-CCP titer

\begin{tabular}{lll}
\hline & DKK-1 & \\
\hline Anti CCP & $r$ & $P$ value \\
& 0.870 & $0.001^{*}$
\end{tabular}

DKK-1 Dickkopf-1, anti-CCP anti-cyclic citrullinated peptide antibody, Pearson's correlation coefficient, ${ }^{*} \leq \leq 0.05$ indicates significant difference
The aim of this work was to study the prognostic role of circulating DKK-1 in the pathogenesis of RA and its correlation to other laboratory markers of disease activity.

The results of this work showed no significant difference between the studied groups according to age and sex (Table 1).

As regards ESR, we found that the values of ESR were significantly high in RA patients in comparison to healthy subjects (Table 1). These results were in accordance with the results of Daoussis et al. He noticed a significant increase in ESR level in patients of RA compared to controls [21]. Also, we found a significant difference between the studied groups regarding RF (Table 1). These results were in agreement with that of Vittecoq et al. [22] who found that high titer of RF was important in predicting continuation of radiographic damage in RA.

Our results demonstrated that there was no significant difference as regards ESR in RF negative and RF-positive patients (Table 2), and this was in agreement with $\mathrm{Vaj}$ payee et al. who demonstrated that RF showed a low correlation with ESR [23].

Also in our study, a significant difference was found between the studied groups regarding CRP (Table 1). These results were in agreement with that of Raghav et al. who demonstrated that CRP as an acute phase protein was shown to differ by changes in clinical disease activity more than ESR, usually elevated in untreated RA 


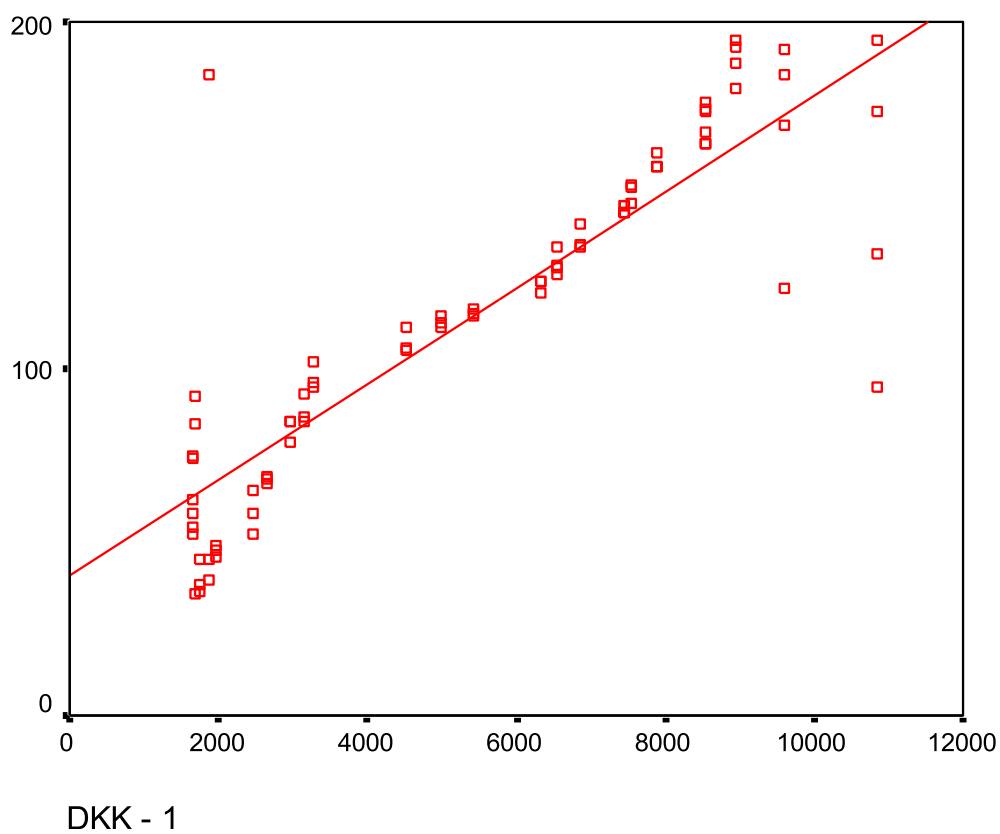

Fig. 5 Correlation between serum DKK-1 levels and anti-CCP titer $(P=0.001)$

and degree of elevation correlated roughly with the severity of inflammation [24].

But in contrary with $\mathrm{Orr} C \mathrm{CK}$ et al. which conducted his study on 223 RA patients with knee arthralgia, synovial examination was done under microscopy using hematoxylin and eosin (H\&E) staining and immunohistochemistry, after synovial samples were taken from the symptomatic knee through arthroscopy. Synovial examination was correlated to DAS28-CRP, ESR, and CRP in the blood samples taken immediately before arthroscopy. They found that, inspite of a significant positive correlation between CRP and inflammation intensity in the biopsy, there was synovial inflammation in patients with normal CRP. They concluded that CRP had a moderate correlation with RA activity [25].

This study showed that there was a positive significant correlation between ESR and DAS 28 (Fig. 3). These results are in disagreement with that of Keenan et al. who demonstrated that poor correlation of ESR with RA activity as ESR is affected by age, sex, menstrual cycles, smoking, drugs, RBC characteristics, and dietary lipids [26].
The results illustrated that DKK-1 levels were significantly high in patients with RA when compared to control group (Table 1). Also, positive correlation was found between DKK-1 and DAS 28 (Table 4, Fig. 2). This matched the results of Diarra et al. who assessed that DKK-1 was closely related to clinical disease activity [18]. We found the same issue with correlation between DKK-1 and Anti-CCP, as we reported a positive significant correlation between them which the matter that support relation of DKK-1 with disease activity (Table 6, Fig. 5). These results were in disagreement with Aydemir $Z S$ et al. who found that, no correlation between markers of RA activity and levels of DKK-1 in patients group [27].

In our results, we reported that DKK-1 showed significant higher levels with longer duration of disease (Table 5, Fig. 4). So, these results were in agreement with Liu et al., 2010 who studied the potential role of DKK-1 in all RA stages. He correlated serum DKK-1 levels in early RA patients in relation with its levels in patients with long duration disease [28] and reported significantly

Table 7 Comparison between DKK-1 levels in patients with versus without bony erosions in hand X-rays

\begin{tabular}{|c|c|c|c|c|c|c|c|c|c|}
\hline DKK-1 (pg/mL) & & Range & & & Mean & \pm & SD & $t$ test & $p$ value \\
\hline \multirow[t]{2}{*}{ Erosions in Hand X-ray } & Present & 1748.9 & - & 10857.5 & 6260.06 & \pm & 2804.28 & 3.660 & $0.001^{*}$ \\
\hline & Absent & 1650.8 & - & 9587.6 & 3923.38 & \pm & 2695.85 & & \\
\hline
\end{tabular}

DKK-1 Dickkopf-1, t. test independent samples $t$ test, ${ }^{*} P \leq 0.05$ indicates significant difference 
Table 8 ROC curve between the studied groups as regards DKK-1

\begin{tabular}{llllllll}
\hline & Cutoff & AUC & Sensitivity & Specificity & PPV & NPV & Accuracy \\
\hline $\begin{array}{l}\text { DKK-1 } \\
\text { (pg/ }\end{array}$ & 2150 & 0.923 & 90 & 85 & 95 & 75 & 82 \\
$\mathbf{m L})$ & & & & & & & \\
\hline
\end{tabular}

DKK-1 Dickkopf-1, cut-off value

higher serum DKK-1 levels in patients with long disease duration, so that bony erosions that usually occur with long disease duration in RA were proved to be associated with increasing serum DKK-1 (Fig. 6). Also, Diarra et al. stated that a profound decrease in levels of DKK-1 was found in RA patients taking anti TNF therapy [18].

Also Garnero et al. underwent assessment of DKK1 levels in a group of randomly selected early RA patients who were receiving disease-modifying antirheumatoid drugs (DMARDs) for only 1 year, and they found higher radiologic progression in patients with higher serum levels of DKK-1. Each 1 (SD) standard deviation increase in serum DKK-1 was correlated with a relative risk of progression of 1.65. So, they suggested that DKK-1 can be as a marker to predict patients who have high risk of progression [29]. These results were in accordance with our study results, as we found that $37.5 \%$ from RA patients who had bony erosions in their plain X-ray of the hands, had higher levels of serum DKK-1 than other patients who had normal X-rays (Table 7).

In contrast to our results, Dalbeth et al. did not detect any significance between serum DKK-1 and bone pathology, and serum levels of DKK-1 had no correlation with the presence of bony erosion or new bone formation [30].

\section{Conclusions}

DKK-l serum level can be used as a potential prognostic biomarker for monitoring of joint erosions and destruction in RA patients. Furthermore, it could be a possible target molecule in the future therapy to control the process of joint destruction.

\section{Limitations}

1. The study had limited number of rheumatoid arthritis patients, and larger number can provide more accurate statistical results.

2. We had no exclusion criteria about drug history that can affects bone metabolism as Parathyroid hormone $(\mathrm{PTH})$, vitamin $\mathrm{D}$, glucocorticoids, and estrogens.

3. We evaluated just the presence or absence of bony erosions at plain X-ray without using Larsen's scoring system.

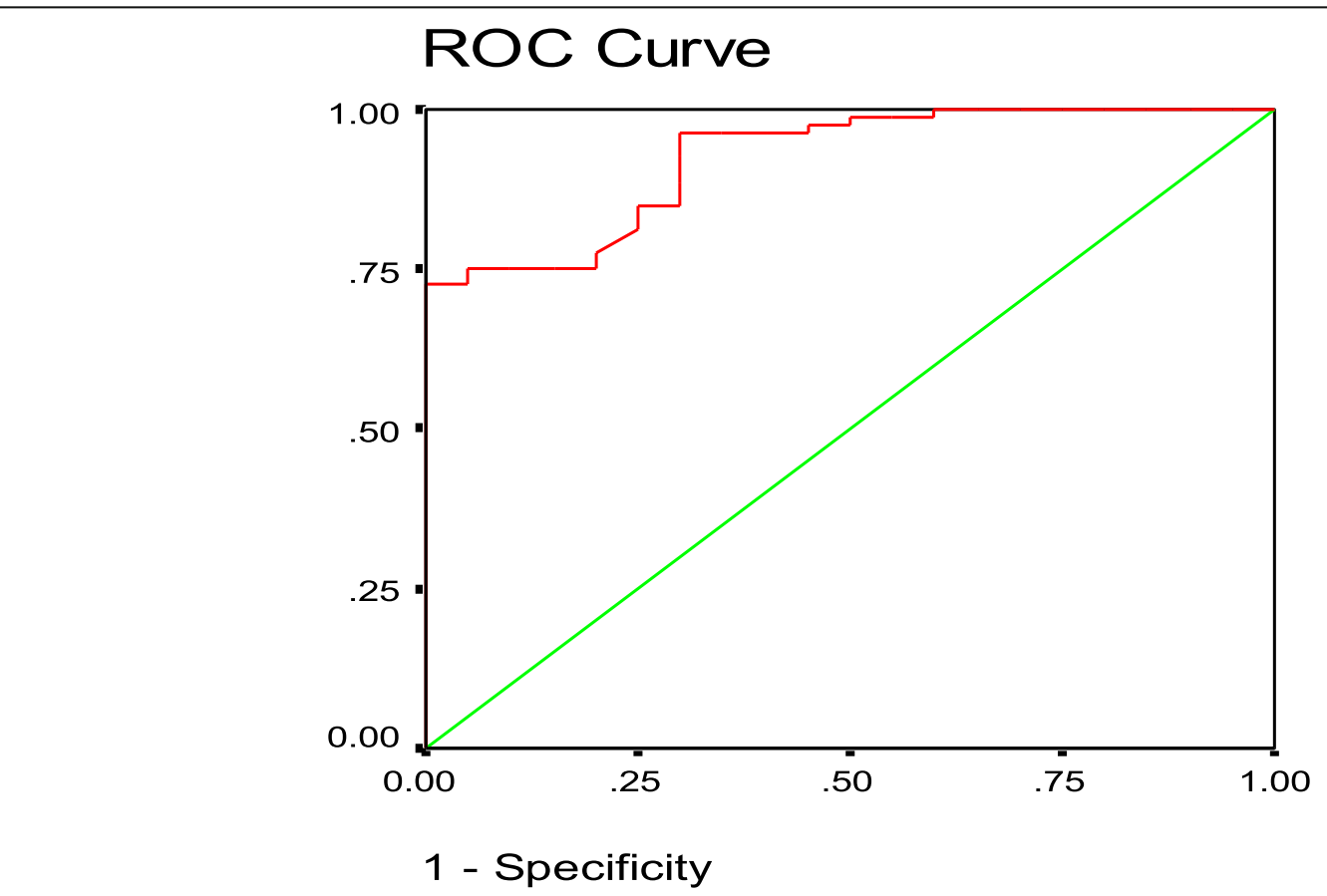

Fig. 6 ROC curve between the studied groups as regard DKK-1 


\section{Abbreviations}

RA: Rheumatoid arthritis; DKK-1: Dickkopf-1; DAS 28: Disease Activity Score using 28 joints count; Anti CCP Ab: Anti-Cyclic Citrullinated Peptide Antibody; Wnt: Wingless/integrated genes; ACR: American College of Rheumatology; EULAR: European League Against Rheumatism; ESR: Erythrocyte sedimentation rate; RF: Rheumatoid factor; CRP: C-reactive protein; H\&E: Hematoxylin and eosin; DMARDs: Disease-modifying antirheumatoid drugs; OPG: Osteoprotegrin; RANKL: Receptor activator of nuclear factor kappa ligand; Fig: Figure

\section{Acknowledgements}

We sincerely thank all patients and healthy subjects for their cooperation in the current study.

\section{Authors' contributions}

DAA: Study designing and retrieving the literature. DAA and RME: performing the routine and molecular investigations and analyzing data. DME: Patients' selection, collecting the data from the patients and control, and performing the clinical examination. HAM: the corresponding author and was involved in writing the manuscript. RLY participated in assessing the patients and writing the manuscript All authors: writing the original draft, reviewing, and final manuscript approval. The authors have read and approved the manuscript.

\section{Funding}

No funding was received.

\section{Availability of data and materials}

All data generated or analyzed during this study are available.

\section{Declarations}

\section{Ethics approval and consent to participate}

This study was approved by the ethics committee of Faculty of Medicine, Tanta University, approval number 33451/5/20, and written informed consent was obtained from all individual participants included in the study.

\section{Consent for publication}

Not applicable

\section{Competing interests}

The authors declare that they have no competing interests.

\section{Author details}

'Department of Clinical Pathology, Faculty of Medicine, Tanta University, Tanta, Egypt. ${ }^{2}$ Department of Physical Medicine and Rehabilitation, Faculty of Medicine, Tanta University, Tanta, Egypt. ${ }^{3}$ Department of Internal Medicine and Rheumatology, Faculty of Medicine, Tanta University, Tanta, Egypt. ${ }^{4}$ Department of Physiology, Faculty of Medicine, Tanta University, Tanta Egypt. ${ }^{5}$ Department of Clinical Pathology, Faculty of Medicine, Tanta University, Tanta, Egypt.

Received: 3 June 2021 Accepted: 22 September 2021

Published online: 09 December 2021

\section{References}

1. Smolen JS, Aletaha D, Barton A, Burmester GR, Emery P, Firestein GS et al (2018) Rheumatoid arthritis. Nat Rev Dis Primers. https://doi.org/10.1038/ nrdp 18001(4):1-23

2. Aletaha D, Smolen JS (2018) Diagnosis and management of Rheumatoid arthritis: a review. JAMA. 320(13):1360-1372. 30285183. https://doi.org/10.1 001/jama.2018.13103

3. Guo Q, Wang Y, Xu D, Nossent J, Pavlos NJ, Xu J (2018) Rheumatoid arthritis: pathological mechanisms and modern pharmacologic therapies. Bone Res. 6(15):1-14. https://doi.org/10.1038/s41413-018-0016-9

4. Heidari B (2011) Rheumatoid arthritis: early diagnosis and treatment outcomes. Caspian J Intern Med 2(1):161-170 PMID: 24024009; PMCID: PMC3766928

5. Haynes DR, Barg E, Crotti TN, Holding C, Weedon H, Atkins GJ, Zannetino A, Ahern MJ, Coleman M, Roberts-Thomson PJ, Kraan M, Tak PP, Smith MD (2003) Osteoprotegerinexpressionin synovial tissue from patients with rheumatoid arthritis, spondylo- arthropathies and osteoarthritis and normal controls. Rheumatology (Oxford). 42(1):123-134. https://doi.org/10.1093/ rheumatology/keg047

6. Vandooren B, Cantaert T, Noordenbos T, Tak PP, Baeten D (2008) The abundant synovial expression of the RANK/RANKL/Osteoprotegerin system in peripheral spondylarthritis is partially disconnected from inflammation. Arthritis. Rheum. 58(3):718-729. 18311801. https://doi.org/10.1002/art.23290

7. Steinhart Z, Angers S (2018) Wnt signaling in development and tissue homeostasis. Development. 145(11):1-8. 29884654. https://doi.org/10.1242/ dev.146589

8. Majidinia M, Aghazadeh J, Jahanban-Esfahlani R, Yousefi B (2018) The roles of $\mathrm{Wnt} / \beta$-catenin pathway in tissue development and regenerative medicine. J Cell Physiol 233(8):5598-5612. https://doi.org/10.1002/jcp.26265 Epub 2018 Mar 7. PMID: 29150936

9. Kabashima K, Sakabe J, Yoshiki R, Tabata Y, Kohno K, Tokura Y. (2010) Involvement of Wnt signaling in dermal fibroblasts. Am J Pathol. 176(2):721732. doi: https://doi.org/10.2353/ajpath.2010.090454. Epub 2009 Dec 30. PMID: 20042673; PMCID: PMC2808079.

10. Jahoda $C A B$, Gilmore $A C$ (2016) What lies beneath: Wnt/B-catenin signaling and cell fate in the lower dermis. J Invest Dermatol. 136(6):1084-1087. 27212647. https://doi.org/10.1016/j.jid.2016.03.029

11. Ruaro B, Casabella A, Paolino S, Pizzorni C, Ghio M, Seriolo C, Molfetta L, Odetti P, Smith V, Cutolo M (2018) Dickkopf-1 (Dkk-1) serum levels in systemic sclerosis and rheumatoid arthritis patients: correlation with the Trabecular Bone Score (TBS). Clin Rheumatol. 37(11):3057-3062. https://doi. org/10.1007/s10067-018-4322-9

12. Kay J, Upchurch KS (2012) ACR/EULAR 2010 rheumatoid arthritis classification criteria. Rheumatology 51, 51(6, suppl 6):vi5-vi9. https://doi. org/10.1093/rheumatology/kes279

13. Den Broeder AA, Creemers MC, van Gestel AM, van Riel PL (2002) Dose titration using the Disease Activity Score (DAS28) in rheumatoid arthritis patients treated with anti-TNF-alpha. Rheumatology (Oxford). 41(6):638-642. 12048289. https://doi.org/10.1093/rheumatology/41.6.638

14. Dac ie JV, Lewis SM (1991) The erythrocyte sedimentation rate, practica haematology, 7th edn. Churchill Livingstone, Edinburgh, pp 521-534.

15. Aletaha D, Neogi T, Silman AJ, Funovits J, Felson DT, Bingham III CO, Birnbaum NS, Burmester GR, Bykerk VP, Cohen MD, Combe B, Costenbader KH, Dougados M, Emery P, Ferraccioli G, Hazes JMW, Hobbs K, Huizinga TWJ, Kavanaugh A, Kay J, Kvien TK, Laing T, Mease P, Ménard HA, Moreland LW, Naden RL, Pincus T, Smolen JS, Stanislawska-Biernat E, Symmons D, Tak PP, Upchurch KS, Vencovský J, Wolfe F, Hawker G (2010) 2010 rheumatoid arthritis classification criteria: an American College of Rheumatology/ European League Against Rheumatism collaborative initiative. Arthritis \& rheumatism. Sep;62(9):2569-2581. doi: https://doi.org/10.1002/art.27584. PMID: 20872595, 62, 2569, 2581.

16. de Vries-Bouwstra JK, Dijkmans BA, Breedveld FC. (2005) Biologics in early rheumatoid arthritis. Rheumatic Disease Clinics. Nov 1;31(4):745-62. doi: https://doi.org/10.1016/j.rdc.2005.07.003. PMID: 16287595, 762.

17. Taylor P, Gartemann J, Hsieh J, Creeden J (2011) A systematic review of serum biomarkers anti-cyclic citrullinated peptide and rheumatoid factor as tests for rheumatoid arthritis. Autoimmune diseases. 2011:815038-815018. https://doi.org/10.4061/2011/815038. Epub 2011 Sep 11

18. Diarra D, Stolina M, Polzer K, Zwerina J, Ominsky MS, Dwyer D, Korb A, Smolen J, Hoffmann M, Scheinecker C, van der Heide D, Landewe R, Lacey D, Richards WG, Schett G (2007) Dikkopf -1 is a master regulator of joint remodeling. Nat Med. 13(2):156-163. https://doi.org/10.1038/nm1538

19. Daoussis D, Solomou EE, Karampetsou M, Bounia K, Tsanaktsi A, Giannopoulos G. (2008) Th17 cells are increased in patients with active rheumatoid arthritis. Ann Rheum Dis. 67(Suppl II):152.

20. Uderhardt S, Diarra D, Katzenbeisser J, David JP, Zwerina J, Richards W, Kronke G, Schett G. (2010) Blockade of Dickkopf (DKK)-1 induces fusion of sacroiliac joints. Annals of the rheumatic diseases. Mar 1:69(3):592-7. doi: https://doi.org/10.1136/ard.2008.102046. Epub 2009 Mar 19. PMID: 19304568 69, 592, 597

21. Daoussis D, Andonopoulos AP, Liossis SN. (2010) Wnt pathway and IL-17: novel regulators of joint remodeling in rheumatic diseases. Looking beyond the RANK-RANKL-OPG axis. Semin Artheritis Rheum. Apr;39(5):369-83. doi: https://doi.org/10.1016/j.semarthrit.2008.10.008. Epub 2008 Dec 18. PMID: $19095294,39,369,383$

22. Vittecoq O, Pouplin S, Krzanowska K, Jouen-Beades F, Me`nard J.F., Gyyet A., et al. (2003) Le rheumatoid factor is the strongest predictor of radiological 
progression of rheumatoid arthritis in a three-year prospective study in community-recruited patients. Rheumatology. 42(8):939-946. https://doi. org/10.1093/rheumatology/keg257

23. Vajpayee N, Graham SS, Bern S, et al. (2007) Basic examination of blood and bone marrow. In: McPherson RA, Pincus MR, ed. Henry's Clinical Diagnosis and Management by Laboratory Methods. 21 st ed. Philadelphia, PA: Elsevier. 457-483.

24. Raghav SK, Gupta B, Agrawal C, Saroha A, Das RH, Chaturvedi VP, Das HR (2006) Altered expression and glycosylation of plasma proteins in rheumatoid arthritis. Glycoconj J 23(3-4):167-173. https://doi.org/10.1007/s1 0719-006-7922-6

25. Orr CK, Najm A, Young F, McGarry T, Biniecka M, Fearon U, Veale DJ. (2018) The utility and limitations of CRP, ESR and DAS28-CRP in appraising disease activity in rheumatoid arthritis. Frontiers in medicine. Aug 3; 5:185. https:// doi.org/10.3389/fmed.2018.00185, 5

26. Keenan R.T., Swearingen C.J., Y azici Y. (2008) Erythrocyte sedimentation rate and C-reactive protein levels are poorly correlated with clinical measures of disease activity in rheumatoid arthritis, systemic lupus erythematosus and osteoarthritis patients. Clin Exp Rheumatol. Sep-Oct;26(5):814-819. PMID: 19032813.

27. Aydemir ZS, Akgol G, Gulkesen A, Kaya A, Kaman D, Ulusoy H (2020) Clinical correlation and determination of Dkk-1 and sclerostin levels in patients with rheumatoid arthritis. Medicine Science 9(4):1053-1060. https://doi.org/10.54 55/medscience.2020.06.097

28. Liu Yan-Ying, Long Li, Wang Shi-yao, Guo J ian-ping, Ye Hua, Ciu Liu-fu, et al. (2010) Circulating Dikkopf -1 and osteoprotegerin in patients with early and longstanding rheumatoid arthritis. Chinese medical journal. Jun 1;123(11):1407-1412. doi: https/// doi.org/10.3760/cma.jissn.0366-6999.2010.11.010

29. Garnero P, Tabassi NC, Voorzanger-Rousselot. (2008) N. circulating dikkopf -1 and radiological progression in patients with early rheumatoid arthritis treated with etanercept. The Journal of rheumatology. Dec 1;35(12):23132315. DOl: https://doi.org/10.3899/jrheum.080356, 2008

30. Dalbeth N, Pool B, Smith T, Callon KE, Lobo M, Taylor WJ, Jones PB, Cornish J, McQueen FM (2010) circulating mediators of bone remodeling in psoriatic arthritis: implications for disordered osteoclastogenesis and bone erosion. Artheritis Res Ther 12(4):R164. https://doi.org/10.1186/ar3123

\section{Publisher's Note}

Springer Nature remains neutral with regard to jurisdictional claims in published maps and institutional affiliations.

\section{Submit your manuscript to a SpringerOpen ${ }^{\circ}$ journal and benefit from:}

- Convenient online submission

- Rigorous peer review

- Open access: articles freely available online

High visibility within the field

- Retaining the copyright to your article

Submit your next manuscript at $\boldsymbol{\nabla}$ springeropen.com 